\title{
Brentanowski immanentyzm jako prefiguracja Husserlowskiego idealizmu transcendentalnego
}

Celem niniejszego tekstu jest próba przedstawienia wyłożonego w Psychologii z empirycznego punktu widzenia Brentanowskiego immanentyzmu jako prefiguracji Husserlowskiej fenomenologii transcendentalnej. Zagadnienie to wymaga przypomnienia głównych rysów psychologii austriackiego filozofa oraz podania epistemologicznej interpretacji fenomenologii transcendentalnej, co też poniżej uczynimy.

Z szukania ścisłości (strenge) dla filozofii znany jest przede wszystkim Edmund Husserl, który w każdym swoim wprowadzeniu do fenomenologii podejmuje uporczywe starania sformułowania ścisłej filozofii. Poszukiwanie źródeł Husserlowskiej postawy intelektualnej wiedzie nas do jego ścieżki akademickiej, kiedy to jako młody człowiek podejmuje studia z zakresu astronomii, fizyki i matematyki, poznaje Karla Weierstrassa, a później, za namową Thomasa Masaryka, zaczyna uczęszczać na wykłady Franciszka Brentany. Poglądy byłego katolickiego duchownego są dla Husserla na tyle sugestywne, że postanawia on poświęcić całe swoje życie filozofii. Podstawę tej sugestywności należy upatrywać w głoszonej przez austriackiego filozofa koncepcji psychologii, która przyszłemu twórcy fenomenologii daje nadzieję na ścisłość badań filozoficznych. W książce Edmund Husserl: founder of phenomenology Dermot Moran pisze, że autor Badań logicznych chce dokonać w filozofii tego, co w matematyce dokonuje Karl Weierstrass tj. sprowadzić całą filozofię do jednego fundamentu ${ }^{1}$. Fundamentem tym jest niewątpliwie właśnie Brentanowska psychologia opisowa, lecz z czasem podstawę dla wszystkich nauk Husserl upatruje w sformułowanej przez siebie nowej nauce.

Zauważmy, że możemy mówić tutaj o dwóch rodzajach fundamentu: o genetycznie pierwszej nauce, podstawie każdej filozoficznej

1 Zob. D. Moran, Edmund Husserl: founder of phenomenology, Polity Press, Cambridge 2005, s. 16. 
oraz naukowej refleksji, lub o jakiejś dziedzinie bytowej, która stanowi przedmiot - w języku Husserla powiemy obszar - dla 'prima scientia'. Taka dziedzina bytowa może być ujęta jako dziedzina, do której redukuje się każda inna albo po prostu jako dziedzina któraś z kolei, posiadająca $\mathrm{w}$ sobie coś takiego lub wchodząca $\mathrm{w}$ jakieś związki $\mathrm{z}$ innymi dziedzinami, że jest dziedziną pierwszej nauki ${ }^{2}$. Do tego, czy psychologia opisowa i fenomenologia, mające pełnić rolę pierwszej nauki, posiadają takie dziedziny, powracam dalej. Najpierw przywołuję podstawowe poglądy Franciszka Brentany, wyłożone w Psychologii z empirycznego punktu widzenia.

Filozof proponuje, aby za przedmiot psychologii przyjać nie tyle duszę, rozumianą jako nośnik przeżyć, lecz fenomeny tj. zjawiska, a konkretnie fenomeny psychiczne. Oprócz fenomenów psychicznych austriacki uczony wyróżnia jeszcze fenomeny fizyczne, mające być przedmiotem badań przyrodoznawstwa. Powód takiego wyznaczenia przedmiotów P dla psychologii i nauk o przyrodzie leży w podstawowej dystynkcji ontologicznej, przyjętej przez Brentanę, choć nie sformułowanej przez niego. Mam tu na myśli konieczność odróżnienia zjawiska od przedmiotu realnego, dalej nazywanego przeze mnie rzeczą. Rozróżnienie to stanowi główny nerw $\mathrm{m}$. in. brytyjskiego empiryzmu, stąd Brentano przywołuje Locke'owski eksperyment polegający na tym, że do tej samej misy z wodą zanurza się obie ręce, przy czym jedną należy wpierw ogrzać, a drugą ochłodzić. Wtenczas w jednej dłoni odczuwa się ciepło, a w drugiej zimno. Obserwacja nakazuje wrażenie ciepła i zimna umieścić $\mathrm{w}$ doznającym, w jego umyśle, nie zaś w świecie zewnętrznym. Istnieją różne podobne przykłady, które naprowadzają na powyższy wniosek. Dlatego empiryści, a w ślad za nimi i Brentano, dokonują ekstrapolacji i wszystkie zjawiska umieszczają 'in mente'. Spostrzegane przeze mnie drzewo, słyszany śpiew ptaka, odczuwany smak chleba to zjawiska znajdujące się we mnie, podobnież - właściwie przede wszystkim - same przeżycia, a więc przedstawianie sobie czegoś, słuchanie, smakowanie, doznawanie, rozumowanie, pożądanie, nienawidzenie, kochanie itd. Pierwszą grupę przykładów nazywa filozof fenomenami fizycznymi, drugą - psychicznymi. Podmiot poznawczy poznaje tylko zjawiska, którym nie przysługuje realne istnienie, lecz właśnie intencjonalne, dlatego też błędnym będzie stwierdzenie, że przedmiot $\mathrm{P}$ dla przyrodoznawstwa to rzecz.

2 Oczywiście u podstaw powyższych rozróżnień przyjmuję dwa założenia: że dyscypliny naukowe tworzą swoistą strukturę, oraz że czymś zasadnym jest mówić o dziedzinach bytowych i o związkach pomiędzy nimi. Rozważania dotyczące dziedzin $\mathrm{i}$ ich relacji z nauką - przedmiot $\mathrm{P}$ nauki $\mathrm{N}$ - odnajdujemy już w $\S 1$ Psychologii z empirycznego punktu widzenia. Zob. F. Brentano, Psychologia z empirycznego punktu widzenia, przeł. Wł. Galewicz, Wydawnictwo Naukowe PWN, Warszawa 1999, s. 9. 
Psychologia z kolei ma się zajmować fenomenami psychicznymi. Bada je za pomocą trzech narzędzi: spostrzeżenia wewnętrznego, indukcji i dedukcji³. Psycholog powinien dokładnie określić anatomię umysłu - co czyni Brentano, pisząc chociażby o fenomenach i świadomości wewnętrznej - korzystając z intuicyjnego wglądu oraz z obserwacji innych indywiduów psychofizycznych; szczególnie tych posiadających słabszą i mniej rozwiniętą psychikę, np. dzieci lub osoby z upośledzeniem psychicznym. Za pomocą indukcji można dokonywać uogólnień, co ma pozwolić na sformułowanie praw życia umysłowego i na podział fenomenów psychicznych ${ }^{4}$. Jeżeli autora Psychologii z empirycznego punktu widzenia uznaje się za prekursora metody fenomenologicznej, to z pewnością ma się na myśli jego poglądy dotyczące tylko psychologii opisowej i spostrzeżenia wewnętrznego.

Tymczasem nazwa 'psychologia' denotuje w filozofii Brentany dwa jej rodzaje: psychologię genetyczną i opisową. Pierwsza z nich zajmuje się badaniem praw, obejmujących psychiczność i fizyczność. Takie badania wspierają się na założeniu, że istnieje swoisty pomost pomiędzy psychiką a ciałem, który umożliwia wpływ stanów fizycznych na psychiczne oraz tych drugich na te pierwsze. Prawa psychologii genetycznej formułuje się na drodze indukcji, a zatem są one niedokładne, stanowią pewne przybliżenie do prawdy, będące prawdopodobieństwem jej utrafienia. Drugim rodzajem psychologii jest wspomniana już psychologia opisowa, nazywana również przez Brentanę psychognozją lub opisową fenomenologią. Prawa formułowane przez ten rodzaj psychologii nie wynikają z jakichś operacji uogólniania, lecz charakteryzują się ścisłością dokładnością, oczywistością, gwarantowaną przez spostrzeżenie wewnętrzne, resp. refleksję. Barry Smith pisze o tej nauce i jej metodzie:

Właściwie deskryptywna psychologia jest postrzegana przez Brentanę jako Kartezjańska nauka, dostarczająca epistemologicznie pewnych fundamentów zarówno wszystkim dyscyplinom filozoficznym, jak i pozostałym rodzajom naukowej wiedzy. Jednocześnie stanowi dla niego nowy rodzaj empirycznej nauki, z sobie właściwą empiryczną metoda, opartą na zdolności do zauważania psychologicznych różnic pomiędzy odmiennymi rodzajami prostych a złożonych aktów, pomiędzy intuitywnymi a nieintuitywnymi komponentami psychicznych fenomenów, pomiędzy różnymi rodzajami fenomenologicznie danych jakości, granic a kontinuami itd., oraz opartej na naszej zdolności do ujmowania pew-

3 Artur Rojszczak zwraca uwagę na to, że Brentano rozróżnia dwa rodzaje poznania (Erkenntnis): poznanie bezpośrednie i zapośredniczone. Zob. A. Rojszczak, Prawda i oczywistość w filozofii Franciszka Brentany, „Principia”, t. 8-9, 1994, s. 138. Spostrzeżenie wewnętrzne stanowi pierwszy rodzaj, a indukcja i dedukcja drugi.

4 Zob. F. Brentano, Psychologia z empirycznego punktu widzenia, s. 64. 
nych, koniecznych i jasnych relacji, zachodzących pomiędzy tak rozróżnionymi elementami ${ }^{5}$.

Wyniki poznawcze psychologii opisowej - w której odsłania się motyw Kartezjański, leżący u podstaw każdej radykalnie dążącej do ścisłości i wspartej o ewidencję filozofii, mogą stanowić pewne, oczywiste ugruntowanie dla filozofii i nauki; moga je uzasadniać w sensie stanowienia dla nich podstawy prawomocności. Wobec tego psychologia opisowa to 'prima scientia', fundament każdej wiedzy naukowej. Uzasadnienia dla takiej roli psychognozji należy szukać w strukturze rzeczywistości. Wszystko, co wiemy, co myślimy, wyobrażamy sobie, co kochamy, dane nam jest w naszych przeżyciach, stanowi ich treść, stąd, chcąc to badać, zwracamy się do własnego życia umysłowego. Nawet nauki przyrodnicze, według Brentany, za swój przedmiot obierają fenomeny fizyczne, nie rzeczy, a dla tych podstawowym momentem formalnym jest bycie-dla-podmiotu, zaś sposobem istnienia, istnienie 'in mente'. Spróbujmy określić podmiot oraz wszystkie dane mu zjawiska terminem 'cogito'; to ułatwi nam dalsze prowadzenie myśli.

W Kartezjańskiej budowie 'body of knowledge' za punkt wyjścia obiera się 'cogito'. Czyni tak również Brentano i Husserl, właśnie dlatego, że podmiot nie może przekroczyć własnych przeżyć, utrafić czegoś, co jest transcendentne. To jednak nie świadczy jeszcze o sceptycyzmie, czy nawet o solipsyzmie psychologii opisowej i fenomenologii. Twórcy tych nowych nauk są przekonani o przejawianiu się rzeczy w przeżyciach, aczkolwiek twierdzenie takie wymaga uzasadnienia 6 . Próbę budowy ontologicznego modelu przejawiania się rzeczy podmiotowi przedstawia Roman Ingarden, pisząc o czystym przedmiocie intencjonalnym ${ }^{7}$. $\mathrm{W}$ przypadku spostrzeżenia zewnętrznego rzecz dana jest $\mathrm{w}$ przeżyciu jako jego treść. W języku Brentany powiedzielibyśmy, że rzecz przejawia się $\mathrm{w}$ fenomenie fizycznym, będącym treścią fenomenu psychicznego. Ingarden stwierdza, że konsekwencją tego uznania jest przyjęcie istnienia realnego świata - przyczyny zjawisk fizycznych. W swojej rozprawie, zatytułowanej Filozofia w rozumieniu Brentany, opublikowanej w tomie $Z$ badań nad filozofia wspótczesna, polski ontolog interpretuje austriackiego filozofa w duchu Kantowskim ${ }^{8}$, ponieważ, jak podkreśla,

5 B. Smith, Austrian Philosophy. The Legacy of Franz Brentano, Open Court, La Salle 1996, s. 27.

6 Takie uzasadnienie można podać w ramach samej psychologii opisowej i fenomenologii, budując - za pomocą pochodzących z ewidencji wyników poznawczych - ontologię poznania, szczególnie ontologię przedmiotu poznania.

7 Zob. R. Ingarden, Spór o istnienie świata, t. 2, cz. 1 i 2, przeł. D. Gierulanka, PWN, Warszawa 1987, § 46 i n.

8 Zob. idem, Filozofia $w$ rozumieniu Brentany, w: idem, Z badań nad filozofia współczesna, PWN, Warszawa 1963, s. 220. W takim samym duchu interpretuje Brentanę Smith. Zob. B. Smith, Austrian Philosophy, s. 41. 
autor Psychologii z empirycznego punktu widzenia rozróżnia z jednej strony fenomeny fizyczne i psychiczne, a z drugiej niepoznawalne rzeczy same $\mathrm{w}$ sobie, wchodzące $\mathrm{z}$ tymi pierwszymi $\mathrm{w}$ związek przyczynowy. Ingarden dookreśla, że ewentualny świat noumenów zostaje założony dla wyjaśnienia świata zjawisk ${ }^{9}$.

Reasumując, psychologia opisowa jest 'prima scientia' w podwójnym sensie. Po pierwsze, ma wyprzedzać każdą inną naukę w taki sposób, aby wyniki, jakie formułuje, stanowiły dla wyników innych nauk źródło prawomocności. Trafnie ujmuje to Kevin Mulligan i Barry Smith w tekście Franz Brentano on the Ontology of Mind:

A zatem zadanie opisania ostatecznych składników fenomenów psychicznych ma posłużyć jako baza dla 'characteristica universalis', dokładnie w takim sensie w jakim pojmował ją Leibniz, a wcześniej Kartezjusz. Projekt ten, raz zrealizowany, miałby dostarczyć podstawy nie tylko dla genetycznej psychologii, ale i dla logiki, etyki, estetyki, politycznej ekonomii, polityki i socjologii również ${ }^{10}$.

Psychologia opisowa tworzy zatem podstawę dla uprawiania innych nauk nie $\mathrm{w}$ sensie partycypacji $\mathrm{w}$ ich wynikach poznawczych, twierdzeniach i teoriach, lecz w sensie swoistej ramy znaczeniowej. Przykładowo, w odniesieniu do logiki, która ustala warunki prawdziwego sądu, psychologia opisowa wyjaśnia, czym w ogóle jest sąd. Pierwsza nauka dostarcza uzasadnienia poprzez określenie natury przedmiotu P innych nauk. Po drugie, psychologia opisowa jest 'prima scientia', ponieważ zajmuje się właśnie fenomenami psychicznymi, zajmuje się 'cogito', przez które rozumiemy wszystkie przeżycia i ich treści. O ile przyrodoznawstwo ma zajmować się fenomenami fizycznymi, o tyle zbadanie istoty tych fenomenów oraz sposobu uświadamiania ich sobie przez podmiot stanowi zadanie dla psychologii, mogącej się go podjąć dzięki temu, że fenomeny fizyczne stanowią treść fenomenów psychicznych. Dalej, jeżeli fenomeny fizyczne są przedmiotem P dla przyrodoznawstwa, to w pewien sposób, jako składniki świadomości, szerzej 'cogito', są przedmiotem dla psychologii. Zatem pierwszeństwo tej nauki zarysowuje się nam w ogólnej strukturze nauk i w porządku bytowym. W tym ostatnim nie chodzi o jakąś metafizyczną zależność rzeczy od przeżyć, lecz o to, że jednym z poziomów bytowych rzeczywistości jest byt psychiczny,

9 Ingarden zaznacza oczywiście, że Brentano sprzeciwiał się filozofii Kanta, a jego interpretacja myśli Brentanowskiej sprowadza się tylko do wskazania pewnej analogii pomiędzy poglądami tych dwóch filozofów. Stanowisko twórcy psychologii opisowej nazywa on sceptycznym realizmem. Zob. R. Ingarden, Filozofia w rozumiепіи Brentany, s. 221.

10 K. Mulligan, B. Smith, Franz Brentano on the Ontology of Mind, "Philosophy and Phenomenological Research" 1985, nr 45, s. 4. 
mogący poznawać świat tylko z pozycji samego siebie, zgodnie z tym czym jest - a więc mamy tu do czynienia ze swoistym rodzajem transcendentalizmu. Toteż wszystko, co podmiot wie o tym świecie, wie, ponieważ poznaje to dzięki swojej świadomości, ponieważ w świadomości tej odkrywa daną sobie treść i własne władze poznawcze, takie jak: rozumowanie, wyobrażanie sobie.

Zauważmy, że możemy mówić tu o dwóch supozycjach 'cogito': jako 'res cogitans', konkretnym bycie, wchodzącym w skład rzeczywistości oraz o świadomości wraz z całym zasobem treści, jaki w niej odnajdujemy, słowem o tzw. immanencji. Budowy ontologii drugiej supozycji 'cogito' podejmuje się Ingarden w Sporze o istnienie świata, kiedy pisze m.in. o doznawaniu, domniemaniu, czystym Ja, strumieniu świadomości itd. ${ }^{11}$. To właśnie uświadomienie sobie podstawowej dla psychologii opisowej i dla fenomenologii dystynkcji ontologicznej: rzecz-świadomość rzeczy, a co za tym idzie odkrycie immanencji jako koniecznego warunku zajścia poznania, legło u podstaw nowożytnego wyeksponowania pierwszeństwa teorii poznania wobec wszelkich nauk, jak i u podstaw krytyki rozumu.

Koniecznym wydaje się dołączenie istotnej dla tematu uwagi dotyczącej podziału fenomenów. Otóż, Brentano dokonuje go m.in. na podstawie wyróżnienia $\mathrm{w}$ fenomenach psychicznych cechy intencjonalności ${ }^{12}$, gdy pisze:

Każdy fenomen psychiczny charakteryzuje się tym, co średniowieczni scholastycy nazywali intencjonalną (lub też mentalną) inegzystencją pewnego przedmiotu, a co my - jakkolwiek nie całkiem jednoznacznie nazwalibyśmy odniesieniem do pewnej treści, skierowaniem na pewien obiekt (przez który nie należy tu rozumieć czegoś realnego), lub immanentną przedmiotowością ${ }^{13}$.

Cecha ta ma przysługiwać fenomenom psychicznym, ponieważ tylko one zawsze na coś się nakierowują. Włodzimierz Galewicz nie pozostawia złudzeń, że tym czymś są przedmioty znajdujące się w umyśle ${ }^{14}$. $\mathrm{Na}$ tym polega Brentanowski immanentyzm. Akty utrafiają to, co immanentne - obiekty znajdujące się $\mathrm{w}$ umyśle. Te mentalne przedmioty charakteryzują się nie tylko formalnym - charakterystycznym dla feno-

11 Te rozważania można znaleźć w: R. Ingarden, Spór o istnienie świata, t. 2, cz. 1 i 2.

12 Nie tylko intencjonalność, zdaniem Brentany, odróżnia fenomeny psychiczne od fizycznych. Te pierwsze zawsze są przedstawieniami lub mają przedstawienie za podstawę, a także nie są przestrzenne.

13 F. Brentano, Psychologia z empirycznego punktu widzenia, s. 126.

14 Zob. Wł. Galewicz, Brentana anatomia życia psychicznego, w: F. Brentano, Psychologia z empirycznego punktu widzenia, s. XLIX. 
menów - momentem bycia-dla-podmiotu, lecz i fizyczną zależnością od podmiotu, stąd postulowana przez filozofa psychologia genetyczna, mająca tę zależność przebadać.

Husserl odrzuca immanentyzm autora Psychologii z empirycznego punktu widzenia, twierdząc, że w świadomości nie zawiera się efektywnie żaden przedmiot, który miałby z nią wchodzić $\mathrm{w}$ jakąś relację ${ }^{15}$. U podstaw koncepcji inegzystencji leży konkretna ontologia, której Brentano nie rozwija. Mam tu na myśli ontologię formalną. Filozof nie dostrzega podwójnej budowy formalnej fenomenu fizycznego, tzn. nie odróżnia formy tego, co on przedstawia - lub co się w nim przejawia - od formy jego samego tj. formy zjawiska jako takiego. Nie wiemy również nic na temat podmiotu zjawisk. O takim podmiocie, a mam tu na myśli Ja świadomościowe, nie wspomina jeszcze Husserl w Badaniach logicznych, lecz w późniejszych swoich pismach explicite prezentuje pojęcie Ja jako spełniacza aktów. Skoro Brentano nie pisze nic na temat Ja, to próżno również pytać o stosunek Ja do spełnianych przez nie przeżyć i o stopień zaangażowania Ja na różnych poziomach przeżywania. Być może krytyka Brentanowskiego immanentyzmu bierze się z niewłaściwego użycia języka oraz z pewnych historycznych naleciałości. Innymi słowy, z osadów sensu, na jakie natrafiamy myśląc o pojęciu „przedmiot” - sam Ingarden wspomina przecież o różnych rodzajach przedmiotów.

Immanentyzmu nie możemy oczywiście identyfikować $z$ inegzystencją. To drugie stanowisko głosi zawieranie się jakiegoś rodzaju przedmiotu w umyśle - powiemy w immanencji. Inegzystencja zatem zakłada immanentyzm, lecz immanentyzm nie zakłada inegzystencji. O takim immanentyzmie wspomina Edmund Husserl, opisując efektywną świadomość, o której można mówić dzięki wprowadzeniu podstawowej, jak mniemam, dystynkcji ontologicznej dla psychologii opisowej i fenomenologii. Wprowadza ją na początku piątej rozprawy swoich Badań logicznych:

Przykładowo, w przypadku spostrzeżenia zewnętrznego moment barwy, stanowiący realny składnik konkretnego widzenia (w psychologicznym sensie wzrokowego zjawiska spostrzeżeniowego) jest tak samo »treścią przeżywanąu albo »świadomąu, jak charakter spostrzegania i jak całe zjawisko barwnego przedmiotu ${ }^{16}$.

W świadomości ,jest tylko sama świadomość", świadomość czegoś spostrzeganego, wyobrażanego, przypominanego itd., ale nie ma niczego, co by świadomością nie było. Nie ma w świadomości czerwoności

15 E. Husserl, Badania logiczne, t. 2, przeł. J. Sidorek, cz. 1, Wydawnictwo Naukowe PWN, Warszawa 2000, s. 468.

16 Ibidem, s. 435. W wydaniu B zamiast 'psychologicznym' Husserl używa słowa 'fenomenologicznym'. 
jakiejś zewnętrznej rzeczy bądź kształtu, lecz świadomość tej czerwoności i świadomość tego kształtu, dlatego w powyższym cytacie filozof zwraca uwagę na fakt, że nie tylko charakter aktów powinien być nazywany świadomościa, ale i ich treści. Nie można „wejść do świadomości”, nie można nic z jej „wyjąć” ani nic do niej „włożyć”. Husserl konkluduje: „Natomiast sam ten przedmiot, jakkolwiek jest spostrzegany, nie jest przeżywany ani świadomy; podobnie jak spostrzegane na nim zabarwienie"17, stąd wydaje się, że można mówić o homogeniczności immanencji, ponieważ zjawiska są również świadomościa, konkretnie, treścią jakichś przeżyć. Charakteryzują się one efektywnością i adekwatnością, a zatem w spostrzeżeniu immanentnym są samoobecnie dane.

W fenomenologii ejdetycznej nie ma mowy o jakichś przedmiotach istniejących w świadomości. Zamiast nich autor Badań logicznych wspomina o materii aktu, dzięki której dane przeżycie odnosi się do danego przedmiotu, np. w przeżyciu spostrzeżenia filiżanki materią jest filiżanka jako treść tego aktu. Jednak zgodnie z podstawową dystynkcją ontologiczną treść „,filiżanka” nie jest rzeczą, nie jest samą filiżanką. Dobitnie podkreśla to Husserl: „Dla rozważania efektywnie fenomenologicznego sama przedmiotowość jest niczym; jest ona przecież, mówiąc w sposób ogólny, transcendentna wobec aktu"18.

Immanencja Husserlowska - ta z Badań logicznych ${ }^{19}$ - jest homogenicznościa, immanencja Brentanowska natomiast wydaje się niedookreślona - być może Brentano pod pojęciem 'przedmiot' rozumie to, co Husserl pojmuje przez materię aktu. W takim kierunku idzie Twardow$\mathrm{ski}^{20}$, ponieważ z ontologicznego punktu widzenia nie jest jasne, $\mathrm{w}$ jaki sposób 'coś' może znajdować się w świadomości. W przypadku wyróżnienia $\mathrm{w}$ akcie materii i jakości twórca fenomenologii zaznacza, że można tego dokonać tylko na drodze abstrakcji, zatem razem oba momenty tworzą pewnego rodzaju całośćc1.

Możemy w końcu przejść do zasadniczego tematu niniejszego tekstu, czyli do próby wykazania, że Brentanowski immanentyzm jest antycypacją Husserlowskiego idealizmu transcendentalnego. Zagadnienie to jest ściśle związane z interpretacją tego drugiego stanowiska - tu wyróżnia się najczęściej dwie interpretacje: metafizyczną i epistemologiczną - oraz z pojmowaniem tzw. zwrotu transcendentalnego, jaki dokonuje Husserl około roku 1906, co z kolei przekłada się na stosunek,

17 Ibid.

18 Ibid., s. 518.

19 Do immanencji w Idei fenomenologii Husserl zalicza również idealne istoty.

20 K. Twardowski, O treści i przedmiocie przedstawień, przeł. I. Dąbska, w: Wybrane pisma filozoficzne, red. W. Rowicka, H. Zielnikowa, PWN, Warszawa 1965, s. 3-91.

21 E. Husserl, Badania logiczne, t. 2, s. 522 i n. 
zachodzący pomiędzy Badaniami logicznymi a Ideami czystej fenomenologii i fenomenologicznej filozofii.

Zdaje się, że w Polsce na Husserla patrzy się najczęściej oczami Romana Ingardena, który w fenomenologii transcendentalnej upatruje odejście swojego mistrza od pierwotnych poglądów i bez żadnych zastrzeżeń interpretuje ją metafizycznie, z tak wielkim uporem, że - jak pisze Tischner:

Opozycja przeciwko uznawaniu Husserla za »idealistę metafizycznego« zrodziła się również wśród uczniów Ingardena, ale Ingarden pozostawał nieczuły na owe protesty. Jeszcze podczas wykładów w Oslo, jakie miał niedługo przed śmiercia, podkreślał dobitnie rację własnego stanowiska ${ }^{22}$.

Husserlowski idealizm można tymczasem pojmować epistemologicznie, tzn. w taki sposób, że to nie rzeczy są zależne od świadomości, ale tzw. noematy wraz treścią doznaniową (hyletyczną). Te niemiecki filozof definiuje następująco:

Spostrzeżenie na przykład ma swój noemat, a u samego [jego] podłoża swój sens spostrzeżeniowy, tzn. to, co spostrzeżone, jako takie. Również dowolne przypomnienie posiada swoje to, co przy pomniane, jako takie, właśnie jako swe coś dokładnie takiego, jak w nim jest „,domniemane”, „uświadamiane”; sądzenie znów, to, co się są dzi, jako takie, upodobanie-podobające się, jako takieitd. Wszędzie noematyczny odpowiednik, który tutaj ( $\mathrm{w}$ znaczeniu bardzo rozszerzonym) nazywa się „sensem”, należy brać dokładnie tak, tkwi on „immanentnie" w przeżyciu spostrzeżenia, sądzenia, podobania się itd., to znaczy tak, jak jest on nam przez nie dany, gdy w y słu chu je m y jedynie samego tego przeżycia ${ }^{23}$.

Immanentyzm zatem nie znika, chociaż nie jest on sprowadzony tylko do efektywnej sfery. Obejmuje sobą także sferę intencjonalną tj. właśnie noematy, a do tego utrzymana zostaje podstawowa dystynkcja ontologiczna. Co prawda, w powyższym fragmencie Husserl nic o niej nie wspomina, ale słowa te zostały zapisane $\mathrm{w}$ trzecim rozdziale trzeciej części Idei czystej fenomenologii i fenomenologicznej filozofii, a więc po rozdziałach dotyczących redukcji transcendentalnej i czystej świadomości. Jak się okazuje, dwie główne linie interpretacyjne myśli niemieckiego filozofa dotyczą sztandarowych dla fenomenologii transcendentalnej

22 J. Tischner, W kręgu myśli Husserlowskiej, w: Filozofia wspótczesna, red. idem, Instytut Teologiczny Księży Misjonarzy, Kraków 1989, s. 46.

${ }_{23}$ E. Husserl, Idee czystej fenomenologii i fenomenologicznej filozofii, przeł. D. Gierulanka, PWN, Warszawa 1975, s. 285 i n. 
pojęć: redukcji oraz konstytucji. W interpretacji metafizycznej redukcja stanowi Kartezjańskie wątpienie w istnienie świata, tymczasem w ujęciu epistemologicznym operacja epoché pozwala po prostu na czasowe odejście od uznawania istnienia tego, co nazywamy światem realnym i skupienia się na tym, co pozostaje, innymi słowy, w co nie uderza epoché. Tym czymś okazuje się czysta świadomość, jak dodaje Husserl, , [...] z jej czystymi »odpowiednikami świadomościowymi« $[\ldots]^{24}$, czyli z noematami. Podobnie w przypadku procesu konstytucji, jej metafizyczna interpretacja upatruje w niej „wytwarzanie” świata, a epistemologiczna syntezy sensu noematycznego.

W fenomenologii - i to zarówno w ejdetycznej, jak i w transcendentalnej - mamy do czynienia z tym, nazywam 'cogito' w drugiej supozycji, a więc ze strumieniem przeżyć. Podkreślić jednak należy, że do tego strumienia należą również ich treści noematyczne. O tak pojętym 'cogito' czytamy w Ideach czystej fenomenologii i fenomenologicznej filozofii:

Drzewo po prostu, rzecz w przyrodzie, nie jest bynajmniej tym czymś jako drzewo spostrzeżonym jako takim, co jako sens spostrzeżeniowy należy do spostrzeżenia, $\mathrm{i}$ to należy nierozdzielnie [...] Wszystko to, co jest czysto immanentne i po redukcji właściwe przeżyciu, czego nie da się myślowo usunąć z przeżycia takiego, jakie ono w sobie jest, i co w nastawieniu ejdetycznym eo ipso przechodzi w eidos, jest oddzielone przepaściami od całej przyrody i fizyki $[\ldots]^{25}$.

Operacja epoché odsłania różnicę, która w naiwnym nastawieniu naturalnym jest niewidoczna. Rzecz fizyczna to byt samoistny, diametralnie różny od noematu, stąd Husserl pisze, że drzewo-rzecz w odróżnieniu od drzewo-spostrzeżenie można spalić, składa się ono ze składników chemicznych, oddziałuje na nie siła itd. Istnieniem świata realnego twórca fenomenologii się nie zajmuje, nie stanowi ono dla niego przedmiotu refleksji. W swoim tekście Fenomenologia i metafizyka Dan Zahavi zauważa:

Husserl odrzuca w ogóle pytania tego rodzaju, jak i wszystkie kwestie dotyczące istnienia bądź nieistnienia zewnętrznej rzeczywistości, ponieważ są one zagadnieniami metafizycznymi, na które w fenomenologicznej epistemologii nie ma miejsca ${ }^{26}$.

24 Ibidem, s. 95.

25 Ibid., s. 288n.

26 D. Zahavi, Phenomenology and metaphysics, w: Metaphysics, Facticity, Interpretation, red. D. Zahavi, S. Heinämaa \& H. Ruin, Kluwer Academic Publishers, Dordrecht-Boston 2003, s. 3. 
W takim duchu filozof pisze Badania logiczne i książki poświęcone fenomenologii transcendentalnej. Nie ma tam żadnych rozważań metafizycznych - chociaż często twierdzenia dotyczące czystej świadomości zalicza się do metafizycznych - to teoria poznania, która ma przygotować grunt dla każdej dyscypliny filozoficznej, w tym i metafizyki, oraz dla każdej z nauk. W interpretacji metafizycznej pracę fenomenologa transcendentalnego pojmuje się jako szukanie odpowiedzi na pytanie o istnienie świata, w interpretacji epistemologicznej zaś odpowiedzi na pytanie o prawomocność wiedzy ${ }^{27}$. Brak prawomocności jakiejś wiedzy, czym charakteryzuje się wiedza naturalna, nie oznacza jeszcze braku istnienia przedmiotu tej wiedzy. Oczywiście, kwestię istnienia przedmiotu jakiejś wiedzy można poddać badaniu fenomenologicznemu, czym zajmuje się Ingarden w Sporze o istnienie świata ${ }^{28}$, a tym samym szukać prawomocności uznania, np. realnego istnienia świata zewnętrznego.

Zauważmy, że zarówno w okresie Badań logicznych, jak i w okresie transcendentalnym, Husserl dąży do uzyskania sfery 'cogito', w pierwszym okresie nazywając je efektywną świadomością, w drugim czystą świadomością, w której wyróżnia sferę efektywną i intencjonalną. Dopiero po uzyskaniu takiej dziedziny bytowej przechodzi do kolejnego kroku, to jest do badań ejdetycznych. Uzyskanie poznawczego dostępu do immanencji, innymi słowy, wzięcie tylko jej pod uwagę, staje się konieczne, aby budować ścisłą naukę. Skoro nastawieniu naturalnemu brakuje prawomocności, to należy je zawiesić; jak gdyby nie zwracać na nie uwagi. Taki 'immanentny zwrot' jest już właściwie dokonaniem epoché, czyli przeniesieniem uwagi własnego, skupionego na świecie realnym myślenia na swoje przeżycia. Jeśli uznamy 'immanentny zwrot' za zawieszenie tezy generalnej, to musimy uznać, że taką samą operację stosuje już Brentano, tyle że implicite ${ }^{29}$. Świadczy o tym jego immanentyzm. Do 'cogito' należą przecież nie tylko fenomeny psychiczne, ale

27 Dla Husserla prawomocność to ewidencja idealnych związków, eidos.

28 Swoje badania Ingarden nazywa ejdetycznymi, lecz jest to nieco odmienna od Husserlowskiej koncepcja ejdetyki.

29 Pisze o tym David Bell w swojej książce Husserl: „Co trzeba koniecznie podkreślić $\mathrm{w}$ tym miejscu to to, że w procedurze [psychologii opisowej - przyp. M. K.] zewnętrzny, materialny świat całkowicie zanika. Może przesadą jest twierdzić, że Brentanowska fenomenologia w sposób zasadniczy zależy od operacji wzięcia w nawias świata zewnętrznego lub że wymaga modyfikacji naturalnego nastawienia, tak iż uwaga przenosi się z tegoż świata na rzeczywistość zależną od subiektywności - ale jest jasne, że w ramach fenomenologii Brentana nie istnieje żadne odniesienie do świata naturalnego oraz żadne filozoficzne użycie jego koncepcji. Innymi słowy, we wczesnej myśli Brentana mamy do czynienia z wyraźną tendencją do solipsyzmu, tendencją, która wywarła głęboki wpływ zarówno na wczesną jak i na późną filozofię Husserla". Zob. D. Bell, Husserl, Routledge, London 1990, s. 8 i n. 
i fizyczne. Te drugie są przez autora Psychologii z empirycznego punktu widzenia nazywane treścią lub immanentnymi przedmiotami utrafianymi przez podmiot $\mathrm{w}$ aktach, czyli $\mathrm{w}$ fenomenach psychicznych.

Brentanowski immanentyzm, a w ślad za nim pracę Husserla, pojmowałbym jako epistemologiczne badania, które w imię rzetelności i ścisłości skupiają się na 'cogito' jako na jednej z wielu dziedzin bytowych. Obie filozofie spostrzegają w tej dziedzinie wyróżniający ją status pierwszeństwa wobec pozostałych dziedzin. Wyróżnienie to widoczne jest tylko z epistemologicznej perspektywy i uzasadnia je struktura rzeczywistości tzn. wszystko to, co wiemy, wiemy dzięki zachodzącej pomiędzy światem a podmiotem relacji, natomiast $\mathrm{z}$ metafizycznego punktu widzenia taki status wydaje się niewidoczny; w każdym razie jego przyjęcie zawsze pociąga za sobą rozwiązania idealistyczne, spirytualistyczne i mentalistyczne. Toteż ani Brentano, ani Husserl nie szukają metafizycznego związku pomiędzy 'res cogitans' a 'res extensa', lecz źródeł prawomocności, które okazują się Kartezjańskim paradygmatem, a następnie prowadzą $\mathrm{w}$ ramach tego paradygmatu badania, mające stanowić ścisłą podstawę dla filozofii i nauki. I to właśnie w tym na nowo ukonstytuowanym przez Brentanę paradygmacie, w jego zwrocie ku immanencji, upatruję antycypację Husserlowskiej fenomenologii, także tej transcendentalnej.

\section{Brentano's immanentism as a prefiguration of Husserl's transcendental idealism}

\section{Keywords}

Husserl, Brentano, transcendental phenomenology, descriptive psychology, epistemological paradigm

Seeing the anticipation of Husserl's transcendental idealism in Brentano's immanentism may seem an absurd. The absurdity however disappears, whether the philosophy of the phenomenology's founder we consider in the epistemological paradigm. If we take the transcendental phenomenology as a set of procedures designed to intrinsic capture of the phenomena alone (those procedures are based on the fundamental distinction of phenomenology: thing - the consciousness of thing), then all the problems related to the issue of the existence of the natural world disappear. In favour of this interpretation we can suggest The Ideas of the Pure Phenomenology and Phenomenological Philosophy, where is stated that due to the operation of epoché, the "non-existence" of the world is taken only as a test. Husserl in his Logical Studies aspires to a mental absolve and to the capture of the sphere of effective consciousness. What is more, in the scriptures from transcendental period, these efforts become more radical, because their goal is 
now the clear consciousness with a psychological "I" excluded. However, as the effective consciousness from the Studies does not give a metaphysical foundation for the real world, so the absolute residuum does not take a form of an existence base. Such an interpretation of Husserl's transcendental idealism empowers us, as we believe, to the acceptance of the thesis that the main motive of Brentano's descriptive psychology is to obtain the sphere of the "phenomenological evidence", in other words, the sphere of phenomena, sphere, to describe which Husserl solicits for all his life. 